\title{
Dynamic Light Scattering and Viscosimetry of Aqueous Solutions of Pectin, Sodium Alginate and their Mixtures: Effects of Added Salt, Concentration, Counterions, Temperature and Chelating Agent
}

\author{
Aline M. F. Lima, ${ }^{a}$ Valdir Soldi ${ }^{*, a}$ and Redouane Borsali ${ }^{*, b}$ \\ ${ }^{a}$ POLIMAT - Polymeric Materials Group, Chemistry Department, \\ Federal University of Santa Catarina, 88040-900 Florianópolis- SC, Brazil \\ ${ }^{b}$ CERMAV, CNRS, Joseph Fourier University BP53 38041 Grenoble, Cedex 9, France
}

\begin{abstract}
Efeitos de adição de sal, concentração, presença de contraíons, temperatura e agente quelante em soluções aquosas de pectina, alginato de sódio e misturas destes foram analisadas por viscosimetria e espalhamento de luz dinâmico (DLS). A viscosidade intrínseca dos sistemas binários diminuiu com a adição de sal e com o aumento da temperatura, porém, mostrou-se insensível à adição de NaEDTA. Como esperado, a viscosidade intrínseca do sistema ternário alginato/pectina/água foi igual a média da viscosidade intrínseca determinada para os sistemas binários. Estudos de DLS indicaram a ocorrência de uma distribuição bimodal (presença dos modos de relaxação rápido e lento) para ambos os sistemas binários e ternários a $25^{\circ} \mathrm{C}$, refletindo um processo de agregação. No caso do modo lento de relaxação, um aumento significativo do raio hidrodinâmico foi observado tanto para os sistemas binários como ternário, na presença de $\mathrm{NaCl}$ e $\mathrm{KCl}$ a $25^{\circ} \mathrm{C}$. No entanto, a $80^{\circ} \mathrm{C}$, o raio hidrodinâmico correspondente ao modo lento em soluções de $\mathrm{KCl}$ foi praticamente constante para todos os sistemas estudados e não foi observado para o sistema binário alginato/solução aquosa.
\end{abstract}

The effects of added salt, concentration, counterions, temperature and chelating agent on aqueous solutions of pectin, sodium alginate and their mixtures were analyzed by viscosimetry and dynamic light scattering (DLS) techniques. The intrinsic viscosity of the binary systems decreased with the addition of salt and with temperature, while it was found to be insensitive to the addition of NaEDTA. As expected the intrinsic viscosity of the ternary alginate/pectin/water system was equal to the average of the intrinsic viscosity for the binary systems. The DLS studies indicated a bimodal distribution (fast and slow relaxation modes) for both binary and ternary systems at $25^{\circ} \mathrm{C}$, reflecting aggregation. A significant increase in the hydrodynamic radius, in the case of the slow mode, was observed for the binary and ternary systems in the presence of $\mathrm{NaCl}$ and $\mathrm{KCl}$ at $25^{\circ} \mathrm{C}$. However, at $80^{\circ} \mathrm{C}$ the hydrodynamic radius for the slow mode in $\mathrm{KCl}$ solutions was practically constant for all the studied systems, except for the alginate binary solutions in which were not observed.

Keywords: pectin, sodium alginate, viscosity, salt effect, dynamic light scattering

\section{Introduction}

Sodium alginate (SA) and pectin $(\mathrm{P})$ are polyelectrolytes that have been extensively studied due to their renewable and biodegradable nature. They have been used in many industrial applications, such as in packaging, coating or protective films for the shipping and handling of different materials,,$^{1-3}$ and controlled delivery of drugs. ${ }^{4,5}$ They are also used for their pharmacological activity. ${ }^{6-8}$

\footnotetext{
*e-mail: redouane.borsali@cermav.cnrs.fr, vsoldi@qmc.ufsc.br
}

Alginate is a linear polysaccharide derived from brown sea algae and is composed of $(1 \rightarrow 4)$-linked $\beta$-D-mannuronate residues ( $\mathrm{M}$ units) and $(1 \rightarrow 4)$-linked $\alpha$-Lguluronate (G units) in different proportions. ${ }^{9,10}$ The $\mathrm{G}$ and $\mathrm{M}$ units are joined together in homopolymeric blocks (MM and GG) and blocks with alternate sequences (MG). Additionally, the guluronate and mannuronate residues in homopolymeric blocks present ${ }^{1} \mathrm{C}_{4}$ and ${ }^{4} \mathrm{C}_{1}$ conformations, respectively. Due to the ${ }^{1} \mathrm{C}_{4}$ conformation, the $\alpha$-L-guluronate residues present high selectivity to divalent ions. Pectin is a primary polymer obtained from citrus peel or apple pomace and is composed of a linear backbone of randomly connected $(1 \rightarrow 4)$-linked 
$\alpha$-D-galactosyluronic acid units. Pectins are commonly classified into two categories: high and low methoxy pectins, with a high $(\mathrm{DM}>50 \%)$ and low $(\mathrm{DM}<50 \%)$ degree of methoxylation, respectively. ${ }^{11,12}$

The addition of small amounts of electrolytes to polysaccharide solutions, such as alginate and pectin, reduce considerably the viscosity. On the other hand, if a large amount of salt is added, precipitation occurs. ${ }^{13}$ The properties of alginate and pectin solutions are, in general, affected by physical and chemical parameters, such as temperature, polymer chain size, concentration, water miscible solvents, $\mathrm{pH}$, monovalent salts, polyvalent cations and quaternary ammonium compounds. ${ }^{14,15}$

The viscosity of polysaccharides (polyelectrolytes) in "salt-free" solutions is known to present an abnormal behavior, that is, there is a maximum in the reduced viscosity at a certain concentration. ${ }^{16}$ It is only after screening out the electrostatic interactions (addition of salt) that the variation in the reduced viscosity $\left(\eta_{r}\right)$ as a function of concentration, $c$, becomes linear (isoionic conditions) with the concentration (neutral behavior). ${ }^{17}$

Dynamic light scattering (DLS) studies on polyelectrolytes in the absence of salt or at low ionic strength show, in general, the existence of a bimodal time distribution behavior, corresponding to the existence of a fast and a slow relaxation mode. Such observations have been reported for different charged macromolecular systems, including synthetic ${ }^{18-22}$ and biological polyelectrolyte solutions. ${ }^{23-25}$ The fast mode is often interpreted as a process involving the diffusion of single polyions. ${ }^{26}$ On the other hand, the occurrence and physical meaning of the slow mode is still not well understood, but various studies have shown that such processes or dynamics are related to the presence of aggregates or large domains in polyelectrolytes in the order of $100 \mathrm{~nm} \cdot{ }^{12,26}$

Although the effects of the ionic strength, salt concentration and temperature of polyelectrolyte solutions have been extensively studied for many systems using DLS and viscosimetry, the selective interaction with different mono- and divalent cations and the effect of temperature on the systems here studied are not fully understood. The aim of this work was to study the effect of added salt (different types), concentration, addition of chelating agent and temperature using viscosimetry and DLS analysis of binary (alginate/water and pectin/water) systems and their ternary mixtures (alginate/pectin/water).

Considering that the use of alginate is hindered because of its high cost, the use of pectin in the mixtures, which is widely produced in Brazil, is a potential alternative to prepare films for a wide range of industrial applications. Another objective is to gain a better understanding of the properties of alginate/pectin mixtures. Such studies will give information on the percentage of pectin that can be added to the mixture without modifying the desired properties of alginate.

\section{Experimental}

\section{Materials and methods}

Sodium alginate isolated from the brown algae Macrocystis pyrifera and citrus fruit pectin (Sigma Aldrich Cal. Co., St. Louis, USA) were solubilized in Milli-Q water for $24 \mathrm{~h}$, ultracentrifuged at $7000 \mathrm{rpm}$ for $3 \mathrm{~h}$, filtered through 8.0 and $0.8 \mu \mathrm{m}$ Millipore filters, precipitated in ethanol and dried at room temperature. The molecular weights of sodium alginate and pectin, determined through the intrinsic viscosity [ $\eta]$, using the Mark-Houwink equation (equation 1), were 375 and $83 \mathrm{kDa}$, respectively.

$[\eta]=A M^{\alpha}$

The Mark-Houwink constant are $A=7.30 \times 10^{-5}$; $\alpha=0.92$ for alginate ${ }^{27}$ and $A=9.55 \times 10^{-5} ; \alpha=0.73$ for pectin. ${ }^{28}$ The chemical composition of alginate (corresponding to 39\% guluronic $(\mathrm{G})$ and $61 \%$ mannuronic (M) acids) and the degree of pectin esterification (13\%), were determined by infrared and H-NMR spectroscopies, according to Filippov ${ }^{29}$ and Gransdalen ${ }^{30}$, respectively.

"Salt-free" and $0.1 \mathrm{~mol} \mathrm{~L}^{-1} \mathrm{NaCl}$ solutions of pectin with and without $1 \mathrm{mmol} \mathrm{L}^{-1}$ NaEDTA were prepared at room temperature. Alginate samples were dissolved in water, in $0.1 \mathrm{~mol} \mathrm{~L}^{-1} \mathrm{NaCl}$ solution with and without $1 \mathrm{mmol} \mathrm{L}^{-1} \mathrm{NaEDTA}$ at room temperature, and in $0.1 \mathrm{~mol} \mathrm{~L}^{-1} \mathrm{KCl}$ at room temperature and $80{ }^{\circ} \mathrm{C}$. The mixtures were prepared by dissolving alginate and pectin in $0.1 \mathrm{~mol} \mathrm{~L}^{-1} \mathrm{NaCl}$ solution at room temperature. Fifteen milliliters of the sample solutions, previously filtered through a $0.22 \mu \mathrm{m}$ membrane, were loaded into an Ubbelohde capillary. Viscosity measurements were performed using a Schott AVS 360 automatic dilution viscosimeter coupled to a Schott CT 52 water bath. The temperature and the initial pectin concentration were $25.0 \pm 0.2^{\circ} \mathrm{C}$ and $1 \times 10^{-5}-2 \times 10^{-3} \mathrm{~g} \mathrm{~mL}^{-1}$, respectively. The viscosimeter automatically measures the viscosity of the studied systems at different concentrations through automatic dilutions.

Alginate and pectin solutions at a concentration of $0.0018 \mathrm{~g} \mathrm{~cm}^{-3}$ were prepared in Milli-Q water containing $(0.02 \%)$ sodium azide and different salts $(\mathrm{NaCl}$ and $\mathrm{KCl})$ at two concentrations $\left(0.1\right.$ and $\left.0.5 \mathrm{~mol} \mathrm{~L}^{-1}\right)$ with and without addition of NaEDTA (1, 2 and $\left.5 \mathrm{mmol} \mathrm{L}^{-1}\right)$. 
For the mixtures, stock solutions at a concentration of $0.0018 \mathrm{~g} \mathrm{~cm}^{-3}$ for pectin and alginate, in $0.1 \mathrm{~mol} \mathrm{~L}^{-1} \mathrm{KCl}$ and $0.1 \mathrm{~mol} \mathrm{~L}^{-1} \mathrm{NaCl}$, were stirred for $24 \mathrm{~h}$ at room temperature. The mixtures were obtained by combining the desired amount of alginate and pectin stock solution to give the following SA/P ratios: 30/70; 50/50 and 70/30. The mixtures were left to equilibrate at room temperature and $80^{\circ} \mathrm{C}$, for $24 \mathrm{~h}$, with stirring. All solutions were filtered through 0.45 and $0.22 \mu \mathrm{m}$ filters directly into pre-cleaned glass tubes for the DLS studies.

The scattering measurements were performed at a temperature of $25.0 \pm 0.1{ }^{\circ} \mathrm{C}$ using an ALV (Langen, Germany) apparatus equipped with an automatic goniometric table and a temperature controlled sample cell. The scattering experiments were carried out at different angles ranging from $60^{\circ}$ to $140^{\circ}$ corresponding to a wave vector $q$ (equation 2),

$q=\left(\frac{4 \pi}{\lambda}\right) n \sin \left(\frac{\theta}{2}\right)$

where $\lambda$ is the wavelength of the incident beam in a vacuum, $\theta$ is the scattering angle and $n$ is the refractive index (for water, $n=1.33$ ). The full homodyne autocorrelation function of the scattering intensity was obtained using the ALV5000 autocorrelation provided by ALV, Langen, Germany. The measured intensity time correlation function is related to the electric field correlation function according to the Siegert relation (equation 3),

$g^{(2)}(t)=1+\beta\left|g^{(1)}(t)\right|^{2}$

where $\beta$ is the spatial coherence factor dependent upon the geometry of the detection system and the ratio of the intensity scattered by the polymer to that scattered by the solvent. In general, $g^{(1)}(t)$ may be expressed by a continuous distribution of decays (equation 4).

$g^{(1)}(t)=\int A(\Gamma) \exp (-\Gamma t) d \Gamma$

The autocorrelation functions of the scattered intensity were analyzed by means of the constrained regularization (CONTIN) method developed by Provencher ${ }^{31}$ to obtain the distribution of decay times (or frequencies) and their corresponding amplitude. The diffusion coefficients were calculated from equation 5 , and the equivalent hydrodynamic radius $\left(\mathrm{R}_{\mathrm{H}}\right)$

$D=\left(\Gamma / q^{2}\right)_{q \rightarrow 0}$

was deduced using the Stokes-Einstein relation (equation 6 ), where $k_{B} T$ is the Boltzmann energy and $f$ is the friction coefficient defined by equation 7 , where $\eta_{0}$ is the solvent viscosity.

$D=k_{B} T / f$

$f=6 \pi \eta_{0} R_{H}$

\section{Results and Discussion}

\section{Viscosimetric behavior}

The reduced viscosity of linear polyelectrolytes in dilute solution is dependent on the added salt, the shape and charge of the macromolecules, the concentration, molar mass, the temperature and the counterions. ${ }^{32}$ In Figure 1 , the variation in the reduced viscosity as a function of concentration for pectin (A) and sodium alginate (B) are shown. For pectin, we have reported the viscosity data in water and $0.1 \mathrm{~mol} \mathrm{~L}^{-1} \mathrm{NaCl}$ with and without NaEDTA $\left(1 \mathrm{mmol} \mathrm{L}^{-1}\right)$ at $25^{\circ} \mathrm{C}$. For sodium alginate, the reported viscosity data were taken in water and $0.1 \mathrm{~mol} \mathrm{~L}^{-1} \mathrm{NaCl}$ with and without NaEDTA $\left(1 \mathrm{mmol} \mathrm{L}^{-1}\right)$ and $0.1 \mathrm{~mol} \mathrm{~L}^{-1}$ $\mathrm{KCl}$ at $25^{\circ} \mathrm{C}$. In water, a continuous increase in viscosity with dilution was observed in both binary systems, typical of polyelectrolyte behavior, and all the data are shown in Table 1.

Table 1. Viscosity data for pectin in water and $0.1 \mathrm{~mol} \mathrm{~L}^{-1} \mathrm{NaCl}$ with and without NaEDTA $\left(1 \mathrm{mmol} \mathrm{L}^{-1}\right)$ at $25^{\circ} \mathrm{C}$ and for sodium alginate in water, $0.1 \mathrm{~mol} \mathrm{~L}^{-1} \mathrm{NaCl}$ with and without NaEDTA $\left(1 \mathrm{mmol} \mathrm{L}^{-1}\right)$ and $0.1 \mathrm{~mol} \mathrm{~L}^{-1} \mathrm{KCl}$ at $25^{\circ} \mathrm{C}$ and $80^{\circ} \mathrm{C}$

\begin{tabular}{|c|c|c|c|}
\hline \multirow{2}{*}{ Systems } & \multicolumn{3}{|c|}{$[\eta] / \mathrm{mL} \mathrm{g}^{-1}$} \\
\hline & Pectin & Alginate & Ternary \\
\hline Water at $25^{\circ} \mathrm{C}$ & 1500 & 2379 & \\
\hline $0.1 \mathrm{~mol} \mathrm{~L}^{-1} \mathrm{NaCl}$ at $25^{\circ} \mathrm{C}$ & 380 & 958 & \\
\hline $0.1 \mathrm{~mol} \mathrm{~L}^{-1} \mathrm{NaCl}$ at $25^{\circ} \mathrm{C}(\mathrm{P} / \mathrm{SA}: 70 / 30)^{\mathrm{a}}$ & & & 582 \\
\hline $0.1 \mathrm{~mol} \mathrm{~L}^{-1} \mathrm{NaCl}$ at $25^{\circ} \mathrm{C}(\mathrm{P} / \mathrm{SA}: 50 / 50)^{\mathrm{a}}$ & & & 712 \\
\hline $0.1 \mathrm{~mol} \mathrm{~L}^{-1} \mathrm{NaCl}$ at $25^{\circ} \mathrm{C}(\mathrm{P} / \mathrm{SA}: 30 / 70)^{\mathrm{a}}$ & & & 772 \\
\hline $\begin{array}{l}0.1 \mathrm{~mol} \mathrm{~L}^{-1} \mathrm{NaCl}+1 \mathrm{mmol} \mathrm{L}^{-1} \\
\mathrm{NaEDTA} \text { at } 25^{\circ} \mathrm{C}\end{array}$ & 390 & 895 & \\
\hline $0.1 \mathrm{~mol} \mathrm{~L}^{-1} \mathrm{KCl}$ at $25^{\circ} \mathrm{C}$ & $\mathrm{nd}^{\mathrm{b}}$ & 1160 & \\
\hline $0.1 \mathrm{~mol} \mathrm{~L}^{-1} \mathrm{KCl}$ at $80^{\circ} \mathrm{C}$ & $\mathrm{nd}^{\mathrm{b}}$ & 780 & \\
\hline
\end{tabular}

${ }^{\text {aPectin/sodium alginate mixtures; }{ }^{\mathrm{b}} \text { Not determined }}$

The semi-empirical equation of Fuoss ${ }^{32}$ has been frequently used to determine the [ $\eta]$ values for polyelectrolytes in aqueous solution. ${ }^{33,34}$ In other study, however, this method gives a very high $[\eta]$ value. ${ }^{35}$ For this reason, in this study, the $[\eta]$ values obtained in pure water were fitted using a fourth-order regression method, as reported by Yoo et al. ${ }^{36}$ 

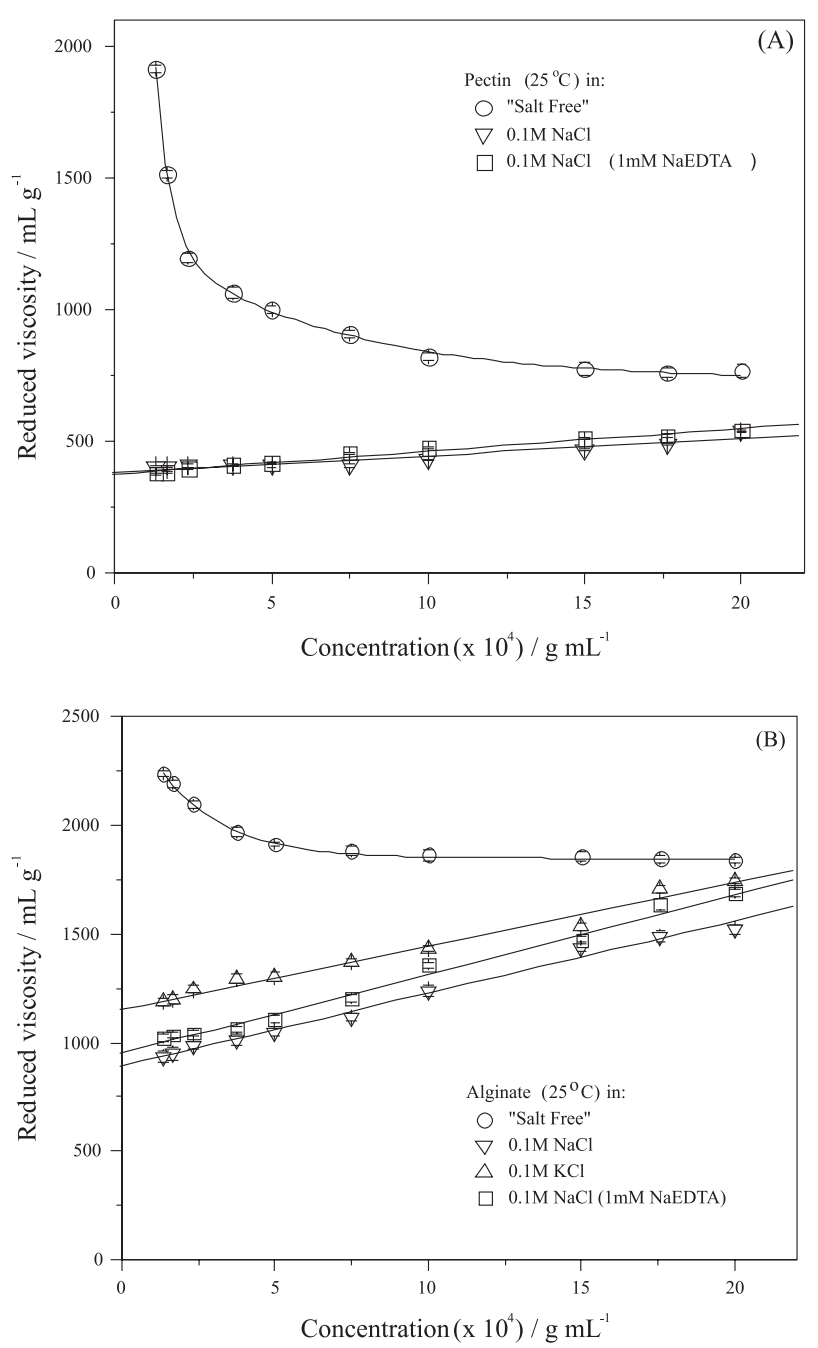

Figure 1. Influence of different solvents on the reduced viscosity of pectin (A) and alginate (B) in: (O) water ("salt free"), ( $\nabla) 0.1 \mathrm{~mol} \mathrm{~L}^{-1} \mathrm{NaCl}$, ( $\square) 0.1 \mathrm{~mol} \mathrm{~L}^{-1} \mathrm{NaCl}$ with $1 \mathrm{mmol} \mathrm{L}-1$ NaEDTA and $(\triangle) 0.1 \mathrm{~mol} \mathrm{~L}^{-1}$ $\mathrm{KCl}$ at $25^{\circ} \mathrm{C}$.

The addition of salt, in general, is used to screen out the electrostatic interactions. ${ }^{37} \mathrm{In}$ the present study, $\mathrm{NaCl}$ and $\mathrm{KCl}$ were used to extract the intrinsic viscosity data for pectin and sodium alginate. After salt addition, pectin shows a linear variation and a large decrease in $[\eta]$ (see Table 1), suggesting that the electrostatic interactions are screened out. A similar behavior (decrease in [ $\eta]$ ) was observed for high and low methoxy pectins with salt addition. ${ }^{36}$ The addition of $1 \mathrm{mmol} \mathrm{L^{-1 }}$ NaEDTA to the pectin or alginate solutions did not result in any significant change.

Our results, however, show that the increase in ionic strength ( $\mathrm{NaCl}$ or $\mathrm{KCl}$ solutions), decreased the alginate viscosity and that the effect was more significant in $\mathrm{NaCl}$ than in $\mathrm{KCl}$. The binding of alkali metal ions to alginate is affected by ionic electronegativity and the hydrated radius, i.e., the electrostatic repulsion along the polyion chain decreases with increasing hydrated radius of the counterions ${ }^{38}$ The ionic radius of $\mathrm{Na}^{+}$is smaller than that of $\mathrm{K}^{+}$, and $\mathrm{Na}^{+}$is more susceptible to hydration and acts as a structure ordering ion. A larger ion such as $\mathrm{K}^{+}$is weakly hydrated and is more likely to interact directly with free carboxyl groups, thereby shielding the interaction. ${ }^{39}$ In the study of $\kappa$-carrageenan gels, Watase and Nishinari ${ }^{40}$ reported that the elastic modulus of gels increased considerably following the addition of alkali metal ions, in the order $\mathrm{Cs}^{+}>\mathrm{K}^{+}>\mathrm{Na}^{+}>\mathrm{Li}^{+}$. In another study, ${ }^{36}$ the effect of $\mathrm{NaCl}$ and $\mathrm{LiCl}$ addition on the $[\eta]$ values was almost negligible for both high- and low-methoxy pectin solutions.

For alginate, the viscosity decreased with increasing the temperature and this effect is irreversible following long term exposure to high temperatures. ${ }^{15}$ When the temperature increases in the presence of $0.1 \mathrm{~mol} \mathrm{~L}^{-1} \mathrm{KCl}$ the reduced viscosity decreases suggesting that the coulombic forces and/or hydrogen bonds are disrupted at higher temperatures (in this case $80^{\circ} \mathrm{C}$ ) (Table 1 ).

It can be noted that in the case of ternary alginate/pectin solutions the intrinsic viscosity was equal to the average of the $[\eta]$ for binary systems, indicating that there is no synergistic effect.

Dynamic light scattering of pectin and sodium alginate solutions

\section{Effect of ionic strength ( $\mathrm{NaCl}$ and $\mathrm{KCl}$ )}

The intensity autocorrelation functions $\left(g^{l}(t)\right)$ for pectin and alginate binary systems under "salt free" conditions, with $0.1 \mathrm{~mol} \mathrm{~L}^{-1} \mathrm{NaCl}$ and with $0.1 \mathrm{~mol} \mathrm{~L}^{-1} \mathrm{KCl}$ (after stirring for $24 \mathrm{~h}$ at $25^{\circ} \mathrm{C}$ ) are shown in Figures 2A and 2B. The corresponding relaxation time distributions obtained from the inverse Laplace transformation of $\left(g_{l}(t)\right)$ using CONTIN showed a bimodal distribution (slow $\left(\Gamma_{\mathrm{s}}\right)$ and fast $\left(\Gamma_{\mathrm{f}}\right)$ modes), as illustrated in Figures 3A and 3B.

When the dynamical behavior is described by two relaxation modes, it is generally accepted that the fast mode $\left(\Gamma_{\mathrm{f}}\right)$ is associated with the relaxation of single molecules and that the slow mode $\left(\Gamma_{s}\right)$ represents the dynamics of large interchain structures (aggregates), as previously reported for pectin systems. ${ }^{26,41,42}$ The presence of a slow mode has been observed in many different systems including low and high ionic strength polyelectrolyte solutions, ${ }^{43,44}$ associating polymer solutions ${ }^{45,46}$ and neutral linear polymer systems in good and in $\theta$ solvents. ${ }^{47,48}$

The salt effect was investigated by comparing the autocorrelation functions in the presence and absence of $\mathrm{NaCl}$ and $\mathrm{KCl}$. It is known that the elastic scattered intensity $\mathrm{I}(q)$ for "salt free" polyelectrolyte systems has a maximum as a function of $q$. This maximum 

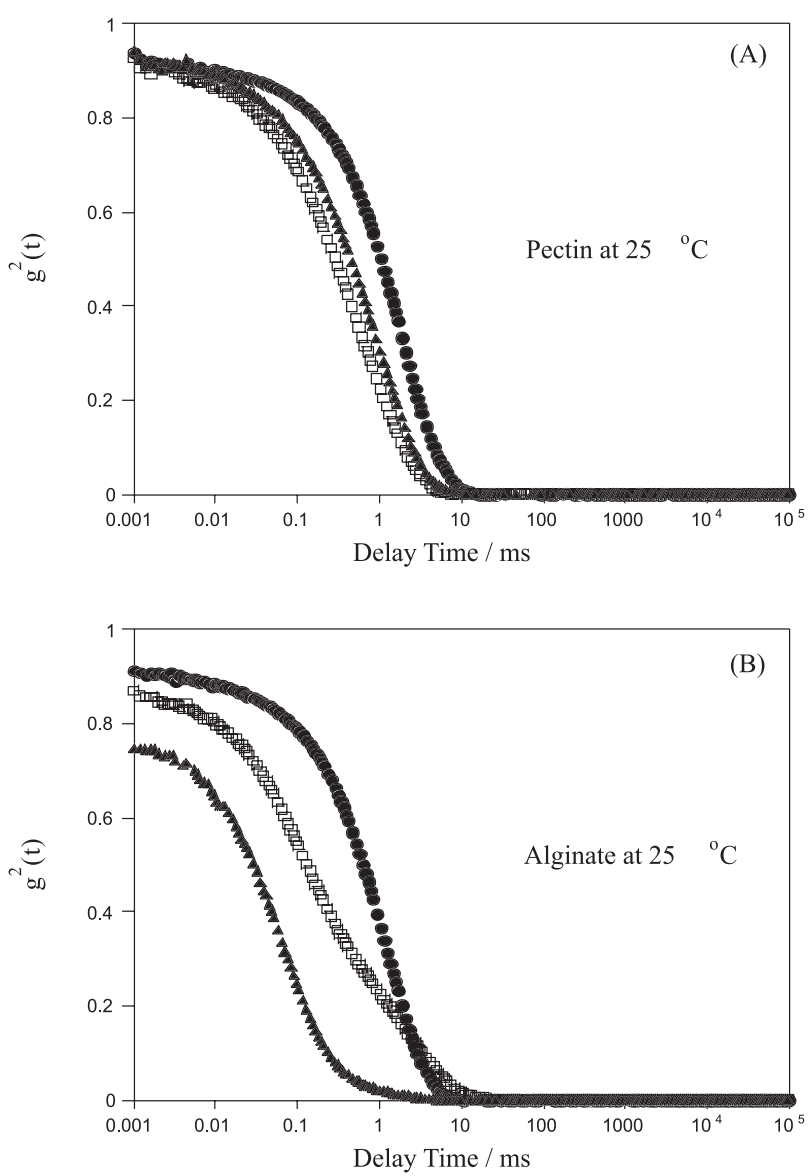

Figure 2. Autocorrelation functions for pectin (A) and alginate (B) solutions at $25{ }^{\circ} \mathrm{C}$ in water $(-)$ with different added salts: $0.1 \mathrm{~mol} \mathrm{~L}^{-1}$ $\mathrm{NaCl}(\square)$ and $0.1 \mathrm{~mol} \mathrm{~L}^{-1} \mathrm{KCl}(\boldsymbol{\Delta})$; measurements carried out at $25^{\circ} \mathrm{C}$ with a scattering angle of $90^{\circ}$.

disappears progressively when salt is added, reflecting the screening of the electrostatic interactions. Such behavior has been observed in many polyelectrolytes systems, for example, in poly(styrenesulfonate) ${ }^{49}$ and several polysaccharides, ${ }^{50-52}$ where the addition of $\mathrm{NaCl}$ to the solutions screens out the electrostatic interactions. In this study, we investigated the effect of $\mathrm{NaCl}$ and $\mathrm{KCl}$ addition on the dynamics of both binary systems. Our results show that the dynamics of the alginate system is more affected by the addition of $\mathrm{KCl}$ than that of the pectin system. One could explain this difference by the fact that the alginate used in this study is rich in mannuronic acid (61\% mannuronic), which due to the ${ }^{4} \mathrm{C}_{1}$ conformation, preferentially interacts with monovalent ions. Considering the two monovalent ions used in this study, the $\mathrm{M}$ blocks has a stronger preference for $\mathrm{K}^{+}(\mathrm{a}$ less hydrated ion with ionic radius $1.33 \AA$ ) than for $\mathrm{Na}^{+}$ (which is a highly hydrated ion with ionic radius $0.95 \AA$ ). Under such conditions, intramolecular interactions of the free guluronic groups could take place, thereby reducing the overall hydrodynamic size $\mathrm{R}_{\mathrm{H}}$ (see Table 2 ).
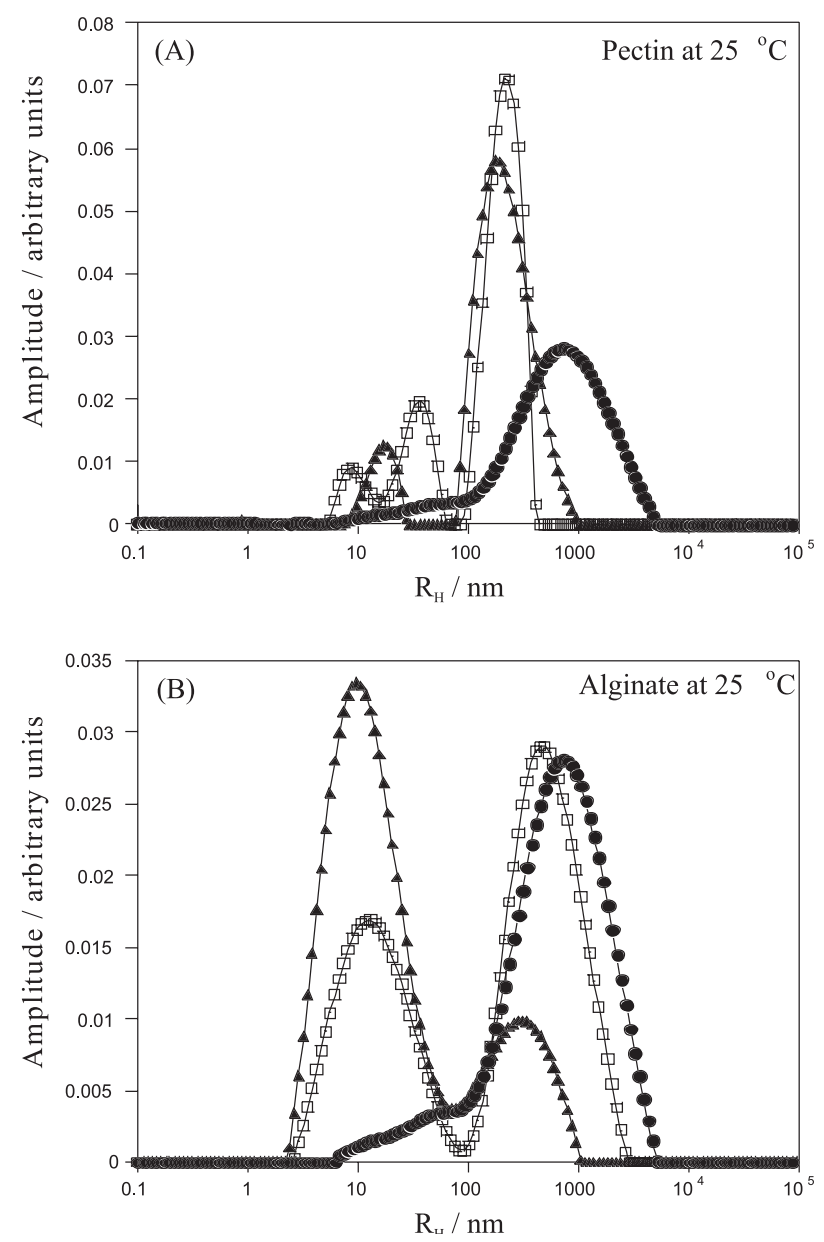

Figure 3. Distribution functions of the hydrodynamic radius obtained from CONTIN method for pectin (A) and alginate (B) solutions stirring for $24 \mathrm{~h}$ at $25^{\circ} \mathrm{C}$ in water $(-)$ and different added salts: $0.1 \mathrm{~mol} \mathrm{~L}^{-1} \mathrm{NaCl}$ ( $\square$ ) and $0.1 \mathrm{~mol} \mathrm{~L}^{-1} \mathrm{KCl}(\boldsymbol{\Lambda})$; measurements carried out at $25^{\circ} \mathrm{C}$ with a scattering angle of $90^{\circ}$.

Table 2. Hydrodynamic radius $\left(\mathrm{R}_{\mathrm{H}}\right)$ for binary pectin and alginate solutions in the presence of $\mathrm{NaCl}$ and $\mathrm{KCl}$ at $25^{\circ} \mathrm{C}$ and $80{ }^{\circ} \mathrm{C}$

\begin{tabular}{|c|c|c|c|c|}
\hline \multirow{3}{*}{ Conditions } & \multicolumn{4}{|c|}{$\mathrm{R}_{\mathrm{H}}(\mathrm{nm})$} \\
\hline & \multicolumn{2}{|c|}{ Pectin $(88 \mathrm{kDa})$} & \multicolumn{2}{|c|}{ Alginate $(375 \mathrm{kDa})$} \\
\hline & $\begin{array}{l}\text { Single } \\
\text { chain }\end{array}$ & Aggregate & $\begin{array}{l}\text { Single } \\
\text { chain }\end{array}$ & Aggregate \\
\hline $0.1 \mathrm{~mol} \mathrm{~L}^{-1} \mathrm{NaCl}$ at $25^{\circ} \mathrm{C}$ & 15 & 187 & 11 & 543 \\
\hline $0.1 \mathrm{~mol} \mathrm{~L}^{-1} \mathrm{NaCl}$ at $80^{\circ} \mathrm{C}$ & 17 & 138 & 10 & 438 \\
\hline $0.1 \mathrm{~mol} \mathrm{~L}^{-1} \mathrm{KCl}$ at $25^{\circ} \mathrm{C}$ & 20 & 195 & 12 & 224 \\
\hline $0.1 \mathrm{~mol} \mathrm{~L}^{-1} \mathrm{KCl}$ at $80^{\circ} \mathrm{C}$ & 25 & 170 & 10 & NA \\
\hline
\end{tabular}

NA: No aggregation.

\section{Effect of temperature}

The associated hydrodynamic radius of pectin solutions were not affected by an increase in temperature from $25{ }^{\circ} \mathrm{C}$ to $80{ }^{\circ} \mathrm{C}$ (Figure $4 \mathrm{~A}$ ). Indeed, the presence of a bimodal correlation function was observed across the whole temperature range. However, one observes a slight 
decrease in the amplitude of the slow mode. On the other hand, for alginate solutions in $0.1 \mathrm{~mol} \mathrm{~L}^{-1} \mathrm{KCl}$ kept under stirring for $24 \mathrm{~h}$, at $80^{\circ} \mathrm{C}$, (Figure $4 \mathrm{~B}$ ), the slow relaxation mode vanishes, suggesting that the increase in entropy (at $80{ }^{\circ} \mathrm{C}$ ) destroyed the interchain interactions involving guluronic groups. Under these conditions the guluronic groups interact more easily with the solvent molecules (water) and, consequently, only free chains are present in the systems.
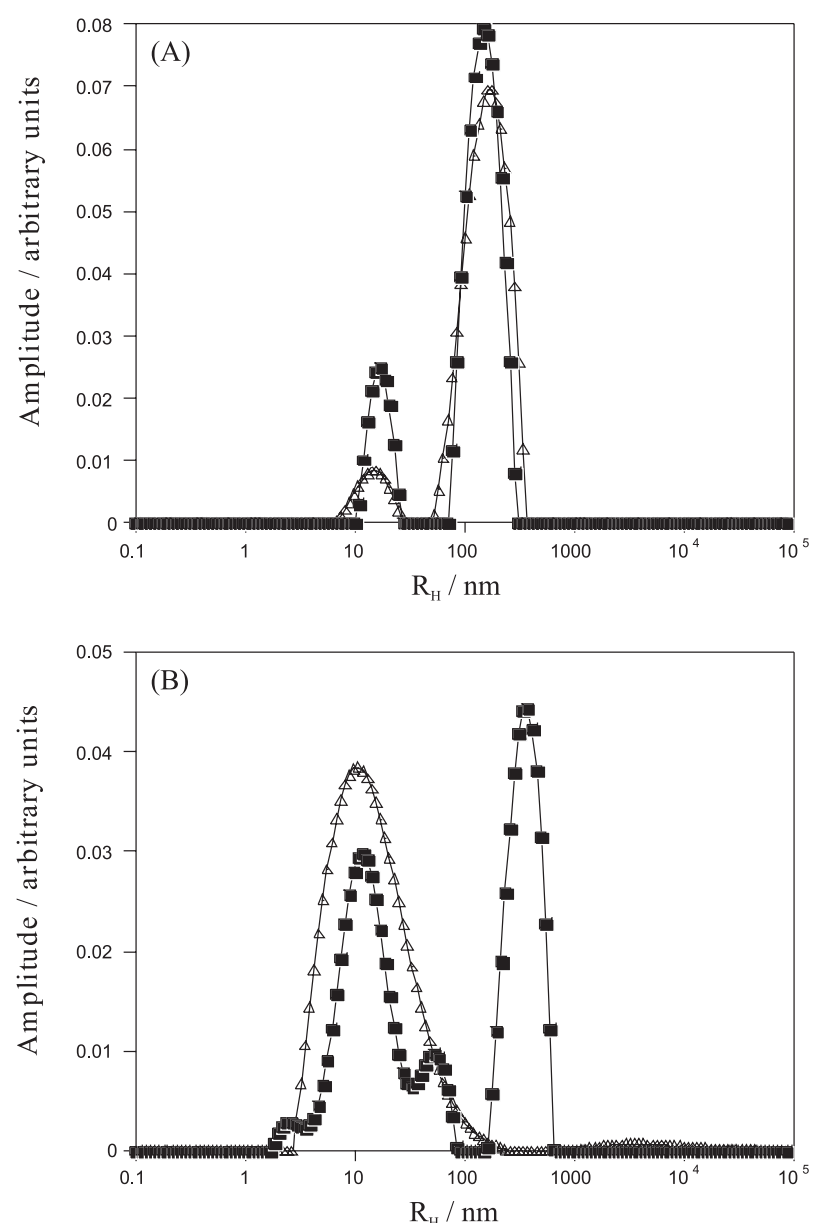

Figure 4. Distribution function of the hydrodynamic radius obtained from CONTIN method for pectin (A) and alginate (B) solutions stirring for 24 $\mathrm{h}$ at $80^{\circ} \mathrm{C}$ in different salts: $0.1 \mathrm{~mol} \mathrm{~L}^{-1} \mathrm{NaCl}(\mathbf{\square})$ and $0.1 \mathrm{~mol} \mathrm{~L}^{-1} \mathrm{KCl}$ $(\triangle)$; measurements carried out at $25^{\circ} \mathrm{C}$ with a scattering angle of $90^{\circ}$.

In Table 2 the hydrodynamic radii $\left(\mathrm{R}_{\mathrm{H}}\right)$ for binary pectin and alginate solutions in the presence of $\mathrm{NaCl}$ and $\mathrm{KCl}$, at $25^{\circ} \mathrm{C}$ and $80^{\circ} \mathrm{C}$, are listed. As observed, the $\mathrm{R}_{\mathrm{H}}$ of the slow mode decreased with increasing temperature for both systems. The results presented here are in agreement with rheological studies carried out by Lootens et al. ${ }^{53}$ and Gilsenan et $a l . .^{54}$, as far as the pectin systems are concerned. In the case of alginate, a significant decrease in $R_{H}$ (aggregates) was observed for $\mathrm{KCl}$ solutions in comparison with $\mathrm{NaCl}$ systems. Considering that the solvation of the
$\mathrm{Na}^{+}$(ionic radius $0.95 \AA$ ) is higher than that of $\mathrm{K}^{+}$(ionic radius $1.33 \AA$ ), a lower $\mathrm{R}_{\mathrm{H}}$ would be expected, because $\mathrm{K}^{+}$ can interact more easily with the carboxylate group than the highest solvated $\mathrm{Na}^{+}$. On the other hand, the single chain pectin system is significantly affected by the temperature and the added salt. The results show that the single chain is more swollen in the case of $\mathrm{KCl}$ than $\mathrm{NaCl}$ and similar results are observed from $25{ }^{\circ} \mathrm{C}$ to $80^{\circ} \mathrm{C}$.

The effects of temperature $\left(25^{\circ} \mathrm{C}\right.$ to $\left.80^{\circ} \mathrm{C}\right)$ and added salt $(\mathrm{KCl}, \mathrm{NaCl})$ do not affect the properties of the alginate single chain.

\section{Effect of chelating agent (NaEDTA)}

In order to better understand the formation of aggregates in salt solutions of pectin and alginate, different concentrations of the chelating agent NaEDTA were added to solutions of pectin and alginate in $0.1 \mathrm{~mol} \mathrm{~L}^{-1}$ and $0.5 \mathrm{~mol} \mathrm{~L}^{-1} \mathrm{NaCl}$. The hydrodynamic radius associated with the fast relaxation mode (single chain) varied with increasing NaEDTA concentration for both systems in $0.1 \mathrm{~mol} \mathrm{~L}^{-1}$ and $0.5 \mathrm{~mol} \mathrm{~L}^{-1} \mathrm{NaCl}$ (Figure 5), whereas, for the slow relaxation mode the $\mathrm{R}_{\mathrm{H}}$ increased in the case of pectin at both $\mathrm{NaCl}$ concentrations. The chelating effect of NaEDTA is associated with the substitution of $\mathrm{Na}^{+}$by traces of ions which can participate in the screening out of the interactions between the galacturonic groups. An increase in the NaEDTA in $\mathrm{NaCl}$ solutions, increases the probability for the formation of multi-chain associations, and this effect is more pronounced in $0.5 \mathrm{~mol} \mathrm{~L}^{-1} \mathrm{NaCl}$. As the $\mathrm{NaCl}$ concentration increases, the system favors the multi-chain associations by polar bonded complexes, and, as a consequence, the $\mathrm{R}_{\mathrm{H}}$ values for both modes increase. For alginate solutions at $0.1 \mathrm{~mol} \mathrm{~L}^{-1}$ and $0.5 \mathrm{~mol} \mathrm{~L}^{-1} \mathrm{NaCl}$, the addition of NaEDTA decreased slightly the $\mathrm{R}_{\mathrm{H}}$ value for the slow mode up to $1 \mathrm{mmol} \mathrm{L}^{-1}$, this value remaining constant at higher NaEDTA concentrations. The observed result (a decrease in $R_{H}$ ) is associated with the interactions between NaEDTA and traces of ions present in solution, which decrease the aggregation between chains. The $\mathrm{R}_{\mathrm{H}}$ values for the two systems in $0.1 \mathrm{~mol} \mathrm{~L}^{-1} \mathrm{NaCl}$, determined at $25^{\circ} \mathrm{C}$ and $80^{\circ} \mathrm{C}$, were, within experimental errors, practically the same.

The dynamical behavior of pectin at $80^{\circ} \mathrm{C}$ was similar to that observed at $25^{\circ} \mathrm{C}$. However, a slight difference was observed in the case of alginate.

In fact, at $80{ }^{\circ} \mathrm{C}$ (Figure 6A), one observes that the relaxation time decreased with an increase in NaEDTA concentration, and at $5 \mathrm{mmol} \mathrm{L}^{-1}$ of NaEDTA the aggregates were progressively destroyed (Figure 6B). This result suggests that the aggregates are formed in the presence of traces of ions in the case of alginate. At the same time, on raising the 

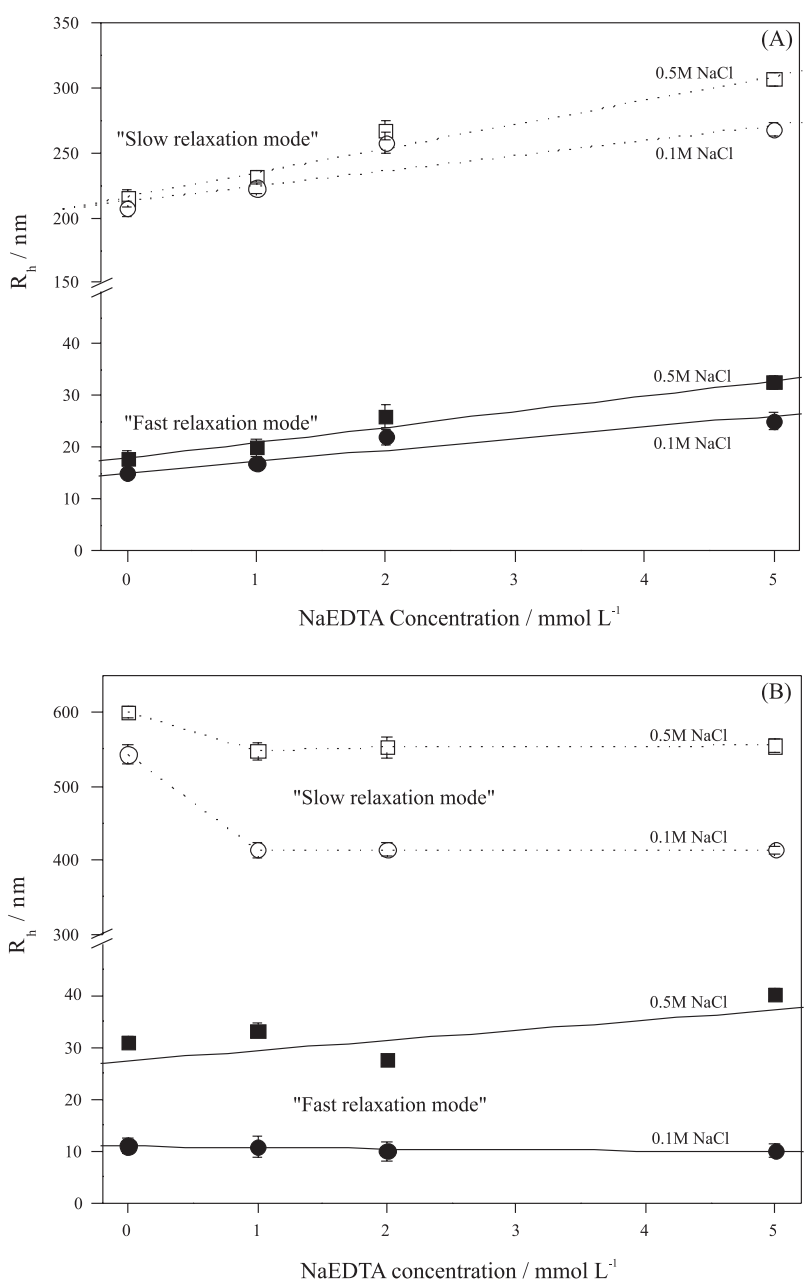

Figure 5. Hydrodynamic radius versus NaEDTA concentration stirring for $24 \mathrm{~h}$ at $25^{\circ} \mathrm{C}$ for pectin (A) and alginate (B) in: $0.1 \mathrm{~mol} \mathrm{~L}^{-1} \mathrm{NaCl}$ for (๑) fast and $(\bigcirc)$ slow relaxation modes; $0.5 \mathrm{~mol} \mathrm{~L}^{-1} \mathrm{NaCl}$ for $(\square)$ fast and $(\square)$ slow relaxation modes. Measurements carried out at $25^{\circ} \mathrm{C}$ with a scattering angle of $90^{\circ}$. The solid and dotted lines represent the free chains and aggregates, respectively.

temperature in an excess of NaEDTA, the dynamics is mainly described by the fast relaxation time (single alginate chain) and a small contribution to the flow frequency.

\section{Dynamic light scattering of ternary pectin and alginate} mixtures

Figure 7 shows the autocorrelation functions measured for ternary alginate/pectin mixtures in comparison with the binary systems, in $\mathrm{KCl}$, after stirring for $24 \mathrm{~h}$ at $25^{\circ} \mathrm{C}$. Similar studies were conducted in the presence of $\mathrm{NaCl}$ and the observed behavior in the case of $\mathrm{KCl}$ was reproducible.

The results show that all the correlation functions are described by two relaxation modes for all the studied compositions (A/P: 0/100, 30/70, 50/50, 70/30, 100/0). The corresponding relaxation time distribution is shown in Figure 7B. The two modes observed for the mixtures at the
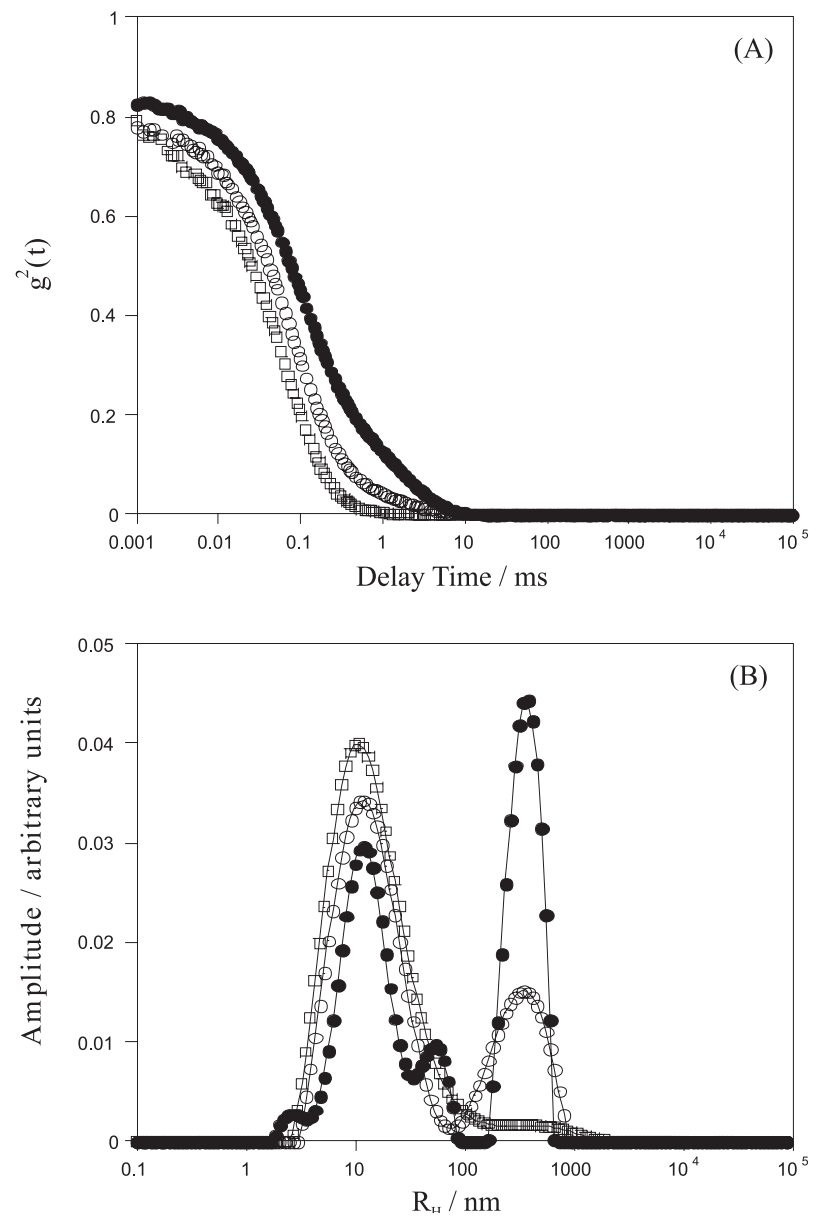

Figure 6. (A) $g^{2}(t)$ versus delay time (ms) and (B) amplitude versus $R_{H}$ for sodium alginate stirring for $24 \mathrm{~h}$ in $0.1 \mathrm{~mol} \mathrm{~L}^{-1} \mathrm{NaCl}$ at $80{ }^{\circ} \mathrm{C}$ with different NaEDTA concentrations $(-) 0 \mathrm{mmol} \mathrm{L}^{-1} ;(\bigcirc) 1 \mathrm{mmol} \mathrm{L}^{-1}$ and (口) $5 \mathrm{mmol} \mathrm{L}^{-1}$; measurements carried out at $25^{\circ} \mathrm{C}$ with a scattering angle of $90^{\circ}$.

two salt concentrations and at $25{ }^{\circ} \mathrm{C}$ were extracted from CONTIN analysis and are listed in Tables 3 and 4. The results show that in $\mathrm{NaCl}$ and $\mathrm{KCl}$ media the correlation function is represented by two relaxation modes, except for the case of sodium alginate in $\mathrm{KCl}$. In $\mathrm{NaCl}$, the slow $\left(\Gamma_{\mathrm{s}}\right)$ and fast $\left(\Gamma_{\mathrm{f}}\right)$ modes predominated in mixtures with high and low pectin content, respectively.

Table 3. Hydrodynamic radius for the fast and slow relaxation modes of pectin/alginate systems in $0.1 \mathrm{~mol} \mathrm{~L}^{-1} \mathrm{NaCl}$ at $25^{\circ} \mathrm{C}$ and $80^{\circ} \mathrm{C}$

\begin{tabular}{lcccc}
\hline \multirow{2}{*}{ Pectin/Alginate } & \multicolumn{2}{c}{$0.1 \mathrm{~mol} \mathrm{~L}^{-1}$} & \multicolumn{2}{c}{$0.1 \mathrm{~mol} \mathrm{~L}^{-1}$} \\
systems & \multicolumn{2}{c}{$\mathrm{NaCl}$ at $25{ }^{\circ} \mathrm{C}$} & \multicolumn{2}{c}{$\mathrm{NaCl}$ at $80^{\circ} \mathrm{C}$} \\
\hline $100 / 0$ & $\mathrm{R}_{\mathrm{H} 1}$ & $\mathrm{R}_{\mathrm{H} 2}$ & $\mathrm{R}_{\mathrm{H} 1}$ & $\mathrm{R}_{\mathrm{H} 2}$ \\
$70 / 30$ & $15.0 \pm 1.5$ & $207.0 \pm 6.2$ & $16.9 \pm 1.3$ & $138.3 \pm 5.1$ \\
$50 / 50$ & $13.9 \pm 0.4$ & $279.5 \pm 5.3$ & $12.9 \pm 0.3$ & $216.2 \pm 4.5$ \\
$30 / 70$ & $13.1 \pm 0.3$ & $312.0 \pm 7.1$ & $12.0 \pm 0.3$ & $237.8 \pm 3.3$ \\
$0 / 100$ & $12.0 \pm 0.3$ & $415.4 \pm 5.3$ & $11.0 \pm 0.4$ & $310.4 \pm 6.2$ \\
$\mathrm{R}_{\mathrm{H} 1}$ and $\mathrm{R}_{\mathrm{H} 2}$ correspond to the fast and slow relaxation modes, respectively.
\end{tabular}


Table 4. Hydrodynamic radius for the fast and slow relaxation modes of pectin/alginate systems in $0.1 \mathrm{~mol} \mathrm{~L}-1 \mathrm{KCl}$ at $25^{\circ} \mathrm{C}$ and $80{ }^{\circ} \mathrm{C}$

\begin{tabular}{lcccc}
\hline $\begin{array}{l}\text { Pectin/ } \\
\text { Alginate } \\
\text { system }\end{array}$ & \multicolumn{2}{c}{$0.1 \mathrm{~mol} \mathrm{~L}{ }^{-1}$} & \multicolumn{2}{c}{$0.1 \mathrm{~mol} \mathrm{~L}^{-1}$} \\
& $\mathrm{R}_{\mathrm{H} 1}$ & $\mathrm{R}_{\mathrm{H} 2}$ & $\mathrm{R}_{\mathrm{H} 1}$ & $\mathrm{R}_{\mathrm{H} 2}$ \\
\hline $100 / 0$ & $20.0 \pm 0.3$ & $196.2 \pm 4.2$ & $24.9 \pm 0.3$ & $172.8 \pm 5.2$ \\
$70 / 30$ & $16.9 \pm 0.4$ & $237.8 \pm 4.7$ & $20.0 \pm 0.4$ & $178.2 \pm 3.4$ \\
$50 / 50$ & $18.1 \pm 0.3$ & $261.2 \pm 5.7$ & $15.9 \pm 0.3$ & $179.9 \pm 5.4$ \\
$30 / 70$ & $15.0 \pm 0.4$ & $295.6 \pm 6.2$ & $12.9 \pm 0.4$ & $181.6 \pm 5.2$ \\
$0 / 100$ & $11.9 \pm 0.3$ & $313.0 \pm 4.1$ & $10.0 \pm 0.5$ & NA \\
\hline
\end{tabular}

$\mathrm{R}_{\mathrm{H} 1}$ and $\mathrm{R}_{\mathrm{H} 2}$ correspond to the fast and slow relaxation modes, respectively. NA: No aggregation
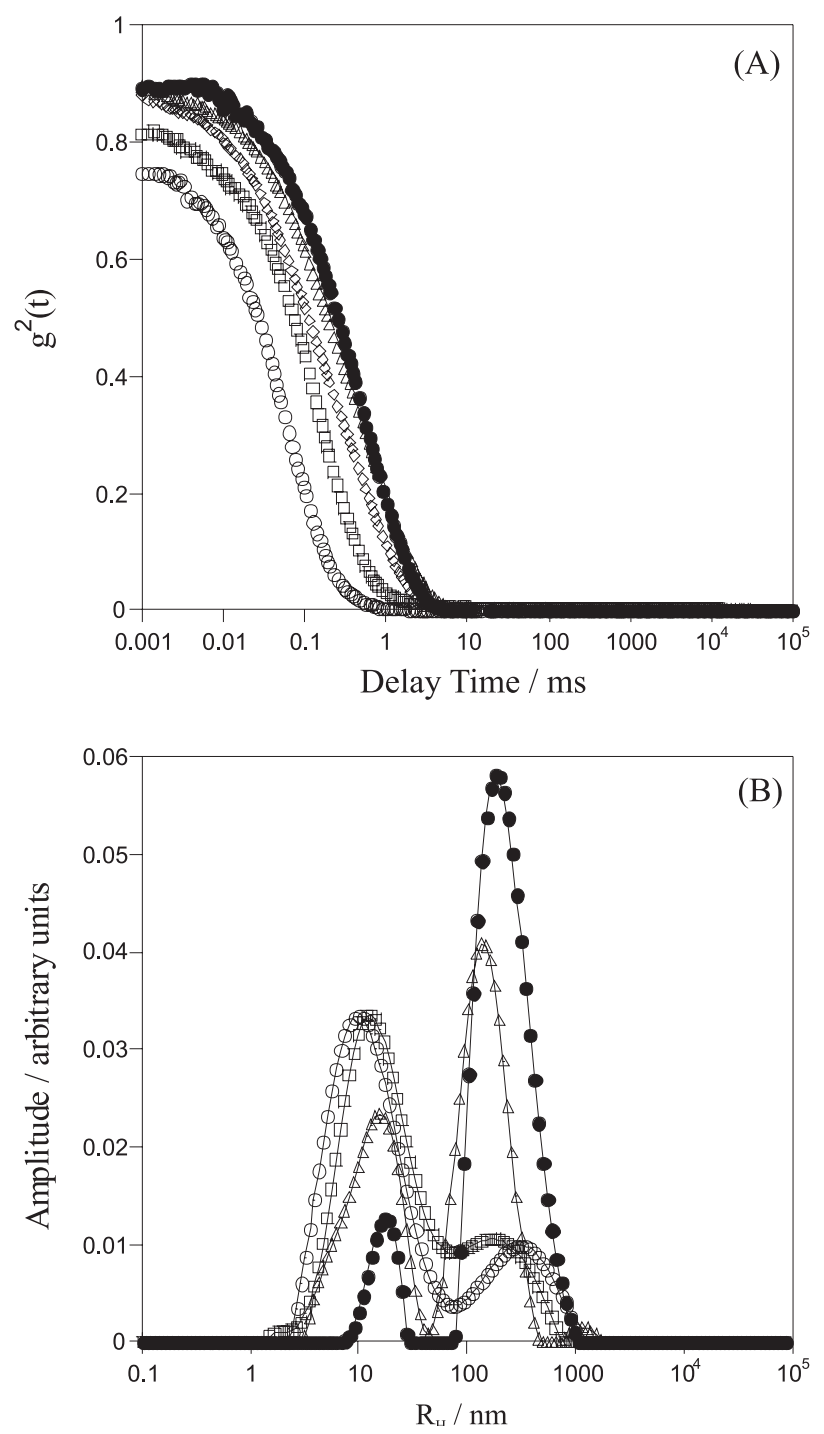

Figure 7. (A) Autocorrelation functions for alginate $(O)$, pectin $(\bullet)$ and their mixtures A/P 30/70 $(\triangle), \mathrm{A} / \mathrm{P} 50 / 50(\diamond)$ and $\mathrm{A} / \mathrm{P} 70 / 30(\square)$ in $\mathrm{KCl}$ solution stirring for $24 \mathrm{~h}$ at $25^{\circ} \mathrm{C}$; measurements carried out at $25^{\circ} \mathrm{C}$ with a scattering angle of $90^{\circ}$. (B) Distribution functions of the hydrodynamic radius obtained from CONTIN analysis for alginate $(O)$, pectin $(\bullet)$ and their mixtures SA/P 30/70 $(\triangle)$ and SA/P 70/30 ( $\square)$ stirring for $24 \mathrm{~h}$ at $25^{\circ} \mathrm{C}$ in $\mathrm{KCl}$; measurements carried out at $25^{\circ} \mathrm{C}$ with a scattering angle of $90^{\circ}$.
Mixtures of two polysaccharides have been, in general, analyzed considering the properties of both binary systems. ${ }^{55-58}$ Interactions between the two components in mixtures can lead to a microstructure totally different from that of the pure polymers, and therefore improve the mechanical and rheological properties. Such effects have been reported, for example, in systems of polygalactans, galactose and glucomannas, as well as xanthan and galactoand glucomannans. ${ }^{59}$ However, for sodium caseinate-xanthan systems it has been reported that the mixtures corresponded to the superposition of the modes of the pure biopolymers, suggesting the absence of interactions between the components in the concentration range studied. ${ }^{60}$

In this study, the sodium alginate/pectin system showed an increase in $\mathrm{R}_{\mathrm{H}}$ after stirring the solutions for $24 \mathrm{~h}$ at $25^{\circ} \mathrm{C}$ and $80^{\circ} \mathrm{C}$, in either $\mathrm{NaCl}$ or $\mathrm{KCl}$. A similar effect has been observed by Hiorth et al. ${ }^{12}$ for chitosan and high pectin content solutions. The authors suggested the formation of large association complexes due to the hydrogen bonds formed between chitosan and pectin.

Figure $8 \mathrm{~A}$ shows the fast mode hydrodynamic radius versus alginate composition for sodium alginate/pectin systems at different salt concentrations and temperatures. Without heating the polymer solutions, the $\mathrm{R}_{\mathrm{H}}$ for the mixtures and pure polymers showed a similar behavior, which was dependent on the volume fraction in either salt, although the $\mathrm{R}_{\mathrm{H}}$ is slightly higher in $\mathrm{KCl}$ than in $\mathrm{NaCl}$. However, at high temperatures an abrupt decrease in the $\mathrm{R}_{\mathrm{H}}$ values was observed in $\mathrm{KCl}$ solutions. The values for $\mathrm{R}_{\mathrm{H}}$ in $\mathrm{NaCl}$ solutions were all higher when stirred at $25^{\circ} \mathrm{C}$ than at $80^{\circ} \mathrm{C}$, except for pure pectin and SA/P 30/70, due to a higher swelling degree of the pectin chain. The same behavior was observed for $\mathrm{R}_{\mathrm{H}}$ in $0.1 \mathrm{~mol} \mathrm{~L}^{-1} \mathrm{KCl}$. The observed behavior is in total agreement with the binary solutions of alginate and pectin, as previously explained.

The hydrodynamic radius of the slow mode (Figure 8B) for the solution prepared at $25^{\circ} \mathrm{C}$ increased with the alginate volume fraction in the mixtures and showed higher values in $\mathrm{NaCl}$ than in $\mathrm{KCl}$. A similar behavior was observed at $80^{\circ} \mathrm{C}$, however, in $\mathrm{KCl}$ solutions the $\mathrm{R}_{\mathrm{H}}$ remained constant for all the volume fractions due to the absence of alginate aggregates at this temperature.

\section{Conclusions}

The reduced viscosity in both binary systems showed a continuous increase as the concentration decreased, which is a typical behavior of polyelectrolytes. However, the intrinsic viscosity decreased in both systems after salt addition and with an increase in temperature (in the case of alginate). The addition of NaEDTA to the binary systems 

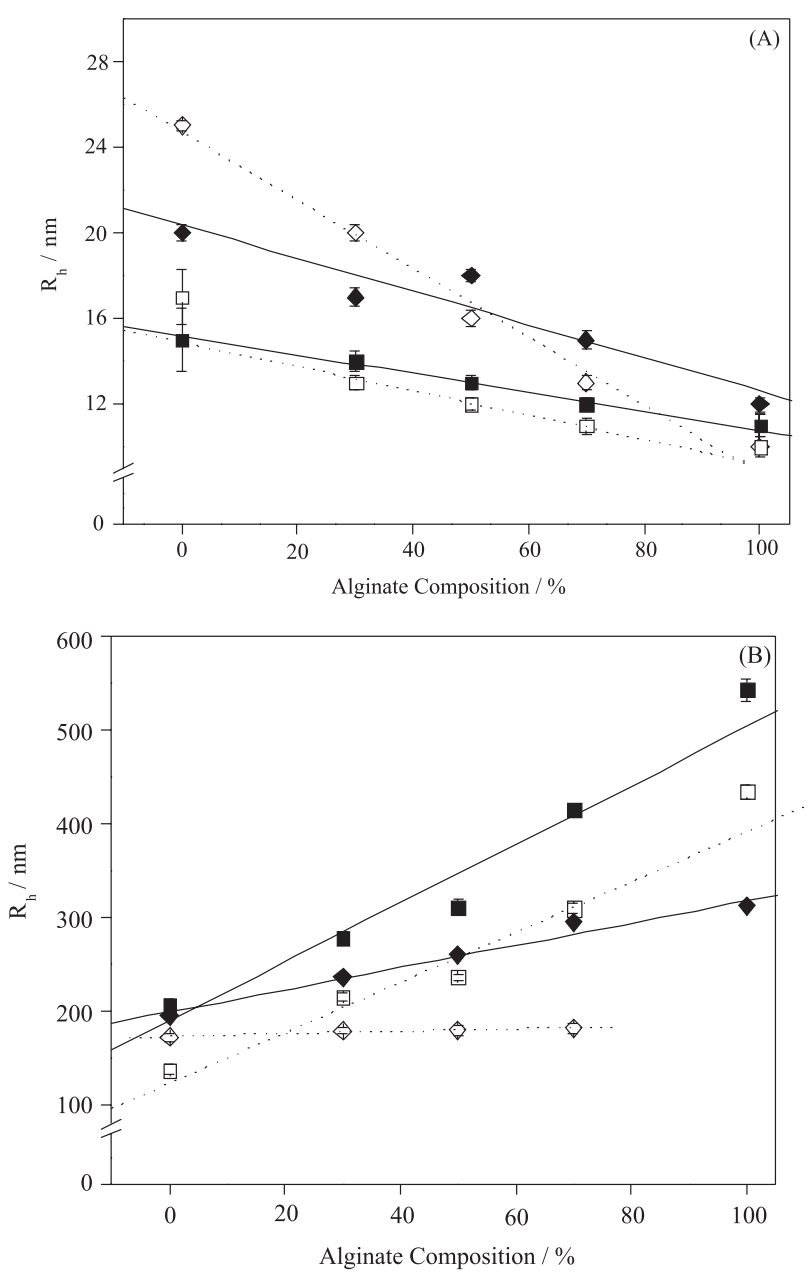

Figure 8. Hydrodynamic radius versus alginate composition for different salts and temperatures, for fast mode (A) and slow mode (B): $0.1 \mathrm{~mol} \mathrm{~L}^{-1}$ $\mathrm{NaCl}$ at $25{ }^{\circ} \mathrm{C}(\square) ; 0.1 \mathrm{~mol} \mathrm{~L}^{-1} \mathrm{KCl}$ at $25{ }^{\circ} \mathrm{C}(\bullet) ; 0.1 \mathrm{~mol} \mathrm{~L}^{-1} \mathrm{NaCl}$ at $80{ }^{\circ} \mathrm{C}(\square)$ and $0.1 \mathrm{~mol} \mathrm{~L}^{-1} \mathrm{KCl}$ at $80^{\circ} \mathrm{C}(\diamond)$.

did not lead to any significant change in the intrinsic viscosity. In the case of ternary systems, the experimental value for the intrinsic viscosity was equal to the average of the intrinsic viscosity for binary systems, indicating that there is no synergistic effect.

The DLS studies indicated a bimodal distribution (fast and slow relaxation modes) for binary systems of alginate and pectin in the absence of salt and in the presence of $\mathrm{NaCl}$ and $\mathrm{KCl}$, at $25^{\circ} \mathrm{C}$. On increasing the temperature to $80^{\circ} \mathrm{C}$, the slow relaxation mode for the alginate system in $\mathrm{KCl}$ disappeared, suggesting that the interactions between adjacent guluronic groups in the chain are screened out. The hydrodynamic radius corresponding to the slow mode for binary pectin and alginate systems in the presence of $\mathrm{NaCl}$ and $\mathrm{KCl}$ decreased with the increase in temperature. In the case of alginate, the effect was more significant in $\mathrm{KCl}$ than in $\mathrm{NaCl}$ solutions. With the addition of NaEDTA, an effect (increase in $R_{H}$ for the slow mode) was observed in the case of the pectin system only.
For the ternary systems, the $\mathrm{R}_{\mathrm{H}}$ for the fast mode decreased with an increase in alginate content for the two salts and temperatures. The opposite behavior (increase in $\mathrm{R}_{\mathrm{H}}$ ) was observed for the slow mode in the ternary systems in $\mathrm{NaCl}$ solutions at $25^{\circ} \mathrm{C}$ and $80{ }^{\circ} \mathrm{C}$. In $\mathrm{KCl}$, the $\mathrm{R}_{\mathrm{H}}$ values for the slow mode increased at $25^{\circ} \mathrm{C}$, and remained practically constant at $80{ }^{\circ} \mathrm{C}$. The $\mathrm{R}_{\mathrm{H}}$ values for the slow mode were lower in $\mathrm{KCl}$ than $\mathrm{NaCl}$ solutions.

\section{Acknowledgements}

The authors gratefully acknowledge CAPES-Brazil (CAPES/COFECUB-348/1 and 620/08) and Federal University of Santa Catarina (UFSC) for the financial support. A part of this work was carried out at LCPOUniversité Bordeaux I.

\section{References}

1. Rhim, J. W.; Wu, Y.; Weller, C. L.; Schnepf, M.; J. Food Sci. 1999, 64, 149.

2. Rhim, J. W.; Lee, J. H.; Hong, S. I.; LWT-Food Sci. Technol. 2006, 39, 806.

3. Maftoonazad, N.; Ramaswamy, H. S.; Marcotte, M.; J. Food Process Eng. 2007, 30, 539.

4. Gilchrist, T.; Martin, A. M.; Biomaterials 1983, 4, 317.

5. Liu, L. S.; Finkenstadt, V. L.; Liu, C. K.; Jin, T.; Fishman, M. L.; Hicks, K. B.; J. Appl. Polym. Sci. 2007, 106, 801.

6. Ashford, M.; Fell, J.; Attwood, D.; Sharma, H.; Woodhead, P.; J. Controlled Release 1993, 26, 213.

7. Rubinstein, A.; Radai, R.; Ezra, M.; Pathak, S.; Rokem, J. S.; Pharm. Res. 1993, 10, 258.

8. Ashford, M.; Fell, J.; Attwood, D.; Sharma, H.; Woodhead, P.; J. Controlled Release 1994, 30, 225.

9. Smidsrod, O.; Skjakbraek, G.; Trends Biotechnol. 1990, 8, 71.

10. Johnson, F. A. ; Craig, D. Q. M. ; Mercer, A. D. ; J. Pharm. Pharmacol. 1997, 49, 639.

11. Kjoniksen, A. L.; Hiorth, M.; Nystrom, B.; Eur. Polym. J. 2004, 40, 2427.

12. Hiorth, M.; Kjoniksen, A. L.; Knudsen, K. D.; Sande, S. A.; Nystrom, B.; Eur. Polym. J. 2005, 41, 1718.

13. Haug, A.; Acta Chem. Scand. 1959, 13, 1250.

14. Walter, R. H.; The Chemsitry and Technology of Pectin, Academic Press, Berlin, Germany, 1991.

15. Day, D. F. Alginates. In Biopolymers from Renewable Resources. Kaplan, D. L.; Springer, San Diego, USA, 1998.

16. Fuoss, R. M.; J. Polym. Sci. 1949, 4, 96.

17. Eisenberg, H.; Pouyet, J.; J. Polym. Sci. 1954, 13, 85.

18. Koene, R. S.; Mandel, M.; Macromolecules 1983, 16, 973.

19. Sedlak, M.; Konak, C.; Stepanek, P.; Jakes, J.; Polymer 1987, 28,873 . 
20. Schmitz, K. S.; Yu, J. W.; Macromolecules 1988, 21, 484.

21. Ermi, B. D. ; Amis, E. J. ; Macromolecules 1996, 29, 2701.

22. Topp, A.; Belkoura, L.; Woermann, D.; Macromolecules 1996, $29,5392$.

23. Lin, S. C.; Lee, W. I.; Schurr, J. M.; Biopolymers 1978, 17, 1041.

24. Mathiez, P.; Mouttet, C.; Weisbuch, G.; Biopolymers 1981, 20 , 2381.

25. Borsali, R.; Nguyen, H.; Pecora, R.; Macromolecules 1998, 31, 1548.

26. Tanahatoe, J. J.; Kuil, M. E.; J. Phys. Chem. B 1997, 101, 9233.

27. Martinsen, A.; Skjakbraek, G.; Smidsrod, O.; Zanetti, F.; Paoletti, S.; Carbohydr. Polym. 1991, 15, 171.

28. Anger, H.; Berth, G.; Carbohydr. Polym. 1986, 6, 193.

29. Filippov, M. P.; Kohn, R.; Chem. Zvesti 1974, $28,817$.

30. Grasdalen, H.; Bakoy, O. E.; Larsen, B.; Carbohydr. Res. 1988, 184, 183.

31. Provencher, S. W.; Comput. Phys. Commun. 1982, 27, 213.

32. Morawetz, H.; Macromolecules in Solution, Wiley: New York, 1975.

33. Yuan, L.; Stivala, S. S.; Doughert.T. J.; J. Polym. Sci. Part A. 1972, 10, 171.

34. Cooper, E. C.; Johnson, P.; Donald, A. M.; Macromolecules 1991, 24, 5380.

35. Michel, F.; Thibault, J. F.; Doublier, J. L.; Carbohydr. Polym. 1984, 4, 283.

36. Yoo, S. H.; Fishman, M. L.; Hotchkiss, A. T.; Lee, H. G.; Food Hydrocolloids 2006, 20, 62.

37. Smidsrød, O.; Haug, A.; Biopolymers 1971, 10, 1213.

38. Zhang, H. C.; Zheng, H. H.; Zhang, Q. Z.; Wang, J. J.; Konno, M.; Biopolymers 1998, 46, 395.

39. Miyata, K.; Kanno, H.; Niino, T.; Tomizawa, K.; Chem. Phys. Lett. 2002, 354, 51.

40. Watase, M.; Nishinari, K.; J. Texture Stud. 1981, 12, 427.

41. Bulone, D.; Martorana, V.; Xiao, C. D.; San Biagio, P. L.; Macromolecules 2002, 35, 8147.
42. Narayanan, J.; Deotare, V. W.; Bandyopadhyay, R.; Sood, A. K.; J. Colloid Interface Sci. 2002, 245, 267.

43. Reed, W. F.; Macromolecules 1994, 27, 873.

44. Ermi, B. D.,Amis, E. J.; Macromolecules 1998, 31, 7378.

45. Klucker, R.; Munch, J. P.; Schosseler, F.; Macromolecules 1997, 30, 3839 .

46. Esquenet, C.; Buhler, E.; Macromolecules 2001, 34, 5287.

47. Adam, M., Delsanti, M.; Macromolecules 1985, 18, 1760.

48. Buhler, E.; Munch, J. P.; Candan, S. J.; J. Phys. II 1995, 5, 765.

49. Drifford, M.; Dalbiez, J. P.; Biopolymers 1985, 24, 1501.

50. Morfin, I.; Reed, W. F.; Rinaudo, M.; Borsali, R.; J. Phys. II 1994, 4, 1001.

51. Borsali, R.; Rinaudo, M.; Noirez, L. Macromolecules 1995, 28 , 1085.

52. Milas, M.; Rinaudo, M.; Duplessix, R.; Borsali, R.; Lindner, P.; Macromolecules 1995, 28, 3119.

53. Lootens, D. ; Capel, F. ; Durand, D. ; Nicolai, T. ; Boulenguer, P. ; Langendorff, V. ; Food Hydrocolloids 2003, 17, 237.

54. Gilsenan, P. M.; Richardson, R. K.; Morris, E. R.; Carbohydr. Polym. 2000, 41, 339.

55. Bergfeldt, K.; Piculell, L.; Linse, P.; J. Phys. Chem. 1996, 100, 3680.

56. Picout, D. R.; Richardson, R. K.; Morris, E. R.; Carbohydr. Polym. 2000, 43, 133.

57. Picout, D. R.; Richardson, R. K.; Rolin, C.; Abeysekera, R. M.; Morris, E. R.; Carbohydr. Polym. 2000, 43, 113.

58. Gilsenan, P. M.; Richardson, R. K.; Morris, E. R.; Food Hydrocolloids 2003, 17, 751.

59. Willians, P. A.; Phillips, G.O.; Interactions in Mixed Polysaccharide Systems. In Food Polysaccharides and Their Applications. Stephen, A. M., Marcel Dekker, New York, USA, 1995, p.463.

60. Nash, W.; Pinder, D. N.; Hemar, Y.; Singh, H.; Int. J. Biol. Macromol. 2002, 30, 269.

Received: December 22, 2008 Web Release Date: September 18, 2009 